\title{
GREEN HALAL PRODUCT: UPAYA PENINGKATAN DESTINASI WISATA BERBASIS SYARIAH
}

\author{
Falikhatun $^{1}$, Salamah Wahyuni ${ }^{2}$, Muthmainah ${ }^{3}$ \\ ${ }^{1}$ Fakultas Ekonomi dan Bisnis, Universitas Sebelas Maret \\ ${ }^{2}$ Fakultas Ekonomi dan Bisnis, Universitas Sebelas Maret \\ ${ }^{3}$ Fakultas Ekonomi dan Bisnis, Universitas Sebelas Maret
}

Falie.feuns17@gmail.com; salamyuni@gmail.com; muthmainah ekis@gmail.com

\begin{abstract}
Abstrak
Salah satu syarat untuk menjadi destinasi wisata syariah adalah tersedianya makanan dan minuman yang terserfifikasi halal.. Berbagai hasil produksi makanan dan minuman dihasilkan oleh Desa Wisata Dewa Emas, antara lain, kerupuk kangkung, hasil olahan ikan, dan minuman herbal. Salah satu produk unggulan yang dihasilkan Desa Wisata ini adalah kerupuk Kangkung dan hasil olahan ikan.. Namun produksi oleh-oleh khas Dewa Emas ini memiliki beberapa kelemahan, antara lain belum tersertifikasi halal dan metoda pemasaran yang masih tradisional. Oleh karena itu tujuan dari pengabdian ini adalah untuk mengurangi beberapa kelemahan tersebut.

Metode pengabdian dilakukan dengan dua cara, yaitu (1) Sosialisasi Sertifikasi Halal, dan (2) Pendampingan pengajuan Sertifikasi Halal. Selanjutnya pengabdian ini diharapkan menghasilkan dua produk berbasis hasil pertanian dan tanaman obat (Green Halal Product), yaitu Kerupuk Kangkung dan Wortel (sudah tersertifikasi Halal) dan serbuk minuman herbal (dalam proses sertifikasi halal).
\end{abstract}

Kata kunci: Dewa Emas; Green Halal Product; Sertifikasi halal; Wisata Syariah

\section{PENDAHULUAN}

Istilah Wisata Syariah di berbagai negara antara lain adalah Islamic tourism, halal tourism, halal travel ataupun as moslem friendly destination (Zamani, 2010). Di Indonesia, istilah untuk menyebut pariwisata berbasis syariah adalah pariwisata syariah yang dituangkan dalam fatwa Dewan Syariah Nasional Majelis Ulama Indonesia No 108 tentang Pedoman Penyelenggaraan Pariwisata Berdasarkan Prinsip Syariah.
Fatwa Dewan Syariah Nasional Majelis Ulama Indonesia No 108 tentang Pedoman Penyelenggaraan Pariwisata Berdasarkan Prinsip Syariah, Pariwisata Syariah (Pariwisata Halal) adalah pariwisata yang sesuai dengan prinsip syariah. Adapun prinsip umum penyelenggaraan pariwisata syariah yang wajib dipenuhi adalah; (1) Terhindar dari kemusyrikan, kemaksiatan, kemafsadatan, tabdzir/israf dan kemunkaran, (2). Menciptakan kemaslahatan dan kemanfaatan baik secara material maupun spiritual (DSN, MUI).

Menurut Widagdo (2015) beberapa karakteristik wisata haal antara lain wisata halal Ekonomi, Sosial, dan Budaya 1041 
bertujuan untuk meningkatkan spritualitas dengan cara menghibur baik untuk dirinya sendiri maupun bersama keluarga atau masyarakat. Selain itu wista halal juga harus memiliki fasilitas ibadah yang menyatu dengan obyek wisata dan ada ritual ibadah yang menjadi bagian dari paket wista tersebut.

Hasil penelitian sebelumnya (Falikhatun, 2017) menunjukkan bahwa beberapa destinasi wisata di Kabupaten Boyolali yang berhasil diidentifikasi meliputi: New Selo (Joglo 2), Bukit Gancik/Gancik Hill Top, Kawasan Wisata Tlatar, Desa Wisata Samiran, Lembah Gunung Madu, Pemandian Umbul Sungsang, Pengging, Candi Lawang, Gedangan, Desa Wisata Dewa Emas, dan Kampung Lele, Tegalrejo, memiliki potensi untuk dikembangkan sebagai destinasi wisata syariah.

Salah satu dari destinasi Wisata Syariah adalah Desa Wisata Dewa Emas. Desa ini terletak di Desa Kemasan yang meupakan salah satu dari 12 desa yang ada di Kecamatan Sawit. Desa Wisata Kemasan terbentuk atas adanya usulan warga setempat untuk mengelola potensi pariwisata yang ada agar dapat meningkatkan taraf perekonomian warga. Selain itu adanya wacana pemerintah pusat mengalokasikan dana bagi desa yang ingin dijadikan konsep desa wisata, sehingga dibentuklah Desa Wisata Kemasan (Dewa Emas). Setelah melalui proses pembangunan di beberapa dukuh yang menjadi sentra Dewa Emas, maka pada bulan April 2014, Dewa Emas resmi dibuka untuk umum.

Dewa Emas ingin memaksimalkan berbagai sumber daya yang ada di dalamnya untuk bisa dinikmati para pengunjung sebagai sebuah wisata sekaligus pendidikan. Wisata yang menjadi pusat Dewa Emas adalah pertanian kangkung dan outbound di Dukuh Mungup, pertanian padi di Dukuh Maron, cara pembuatan berbagai jenis roti di Dukuh Tangkisan, pengolahan sampah terpadu di Dukuh Klegen, serta cara pembuatan jamu di Dukuh Tegalsono. Dewa Emas menggunakan prinsip fun educating dalam kegiatannya, sehingga sasaran utamanya adalah anak-anak dan remaja.
Dewa Emas menawarkan kegiatan wisatanya dalam bentuk paket-paket wisata. Desa Wisata Dewa Emas sudah dikelola oleh Bumdes dan sudah memiliki alamat web tersendiri yaitu www.desawisatakemasan.com. Jumlah pengunjung bisa mencapai 700-1000 orang per bulannya dengan pendapatan mencapai 100 juta per tahunnya.

Wisata yang paling unik adalah Wisata Pentik Kangkung, yang merupakan destinasi wisata unggulan di Desan Kemasan ini. Hasil wisata petik Kangkung, awalnya hanya digunakan sebagai oleholeh tanpa pengolahan, bahkan banyak yang kemudian ditinggal di tempat wisata. Setelah melakukan diskusi dengan beberapa Usaha Kecil Mikro (UKM), kemudian diperoleh ide untuk mengelola Kangkung tersebut. Awalnya hanya dibuat sayur, namun kemudian ada ide untuk mengolah Kangkung menjadi Kerupuk.

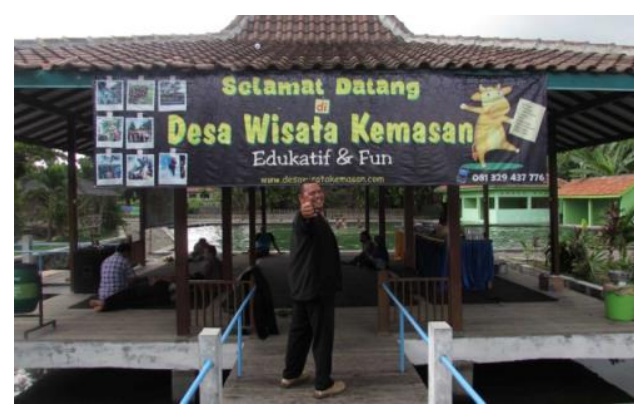

Gambar 1

Pendopo Desa Wisata Kemasan

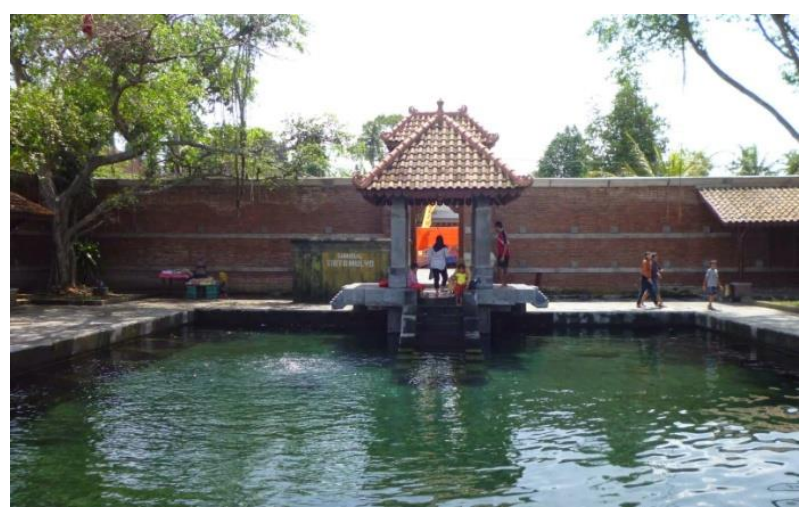

Gambar 2

Umbul Tirto Mulyo 

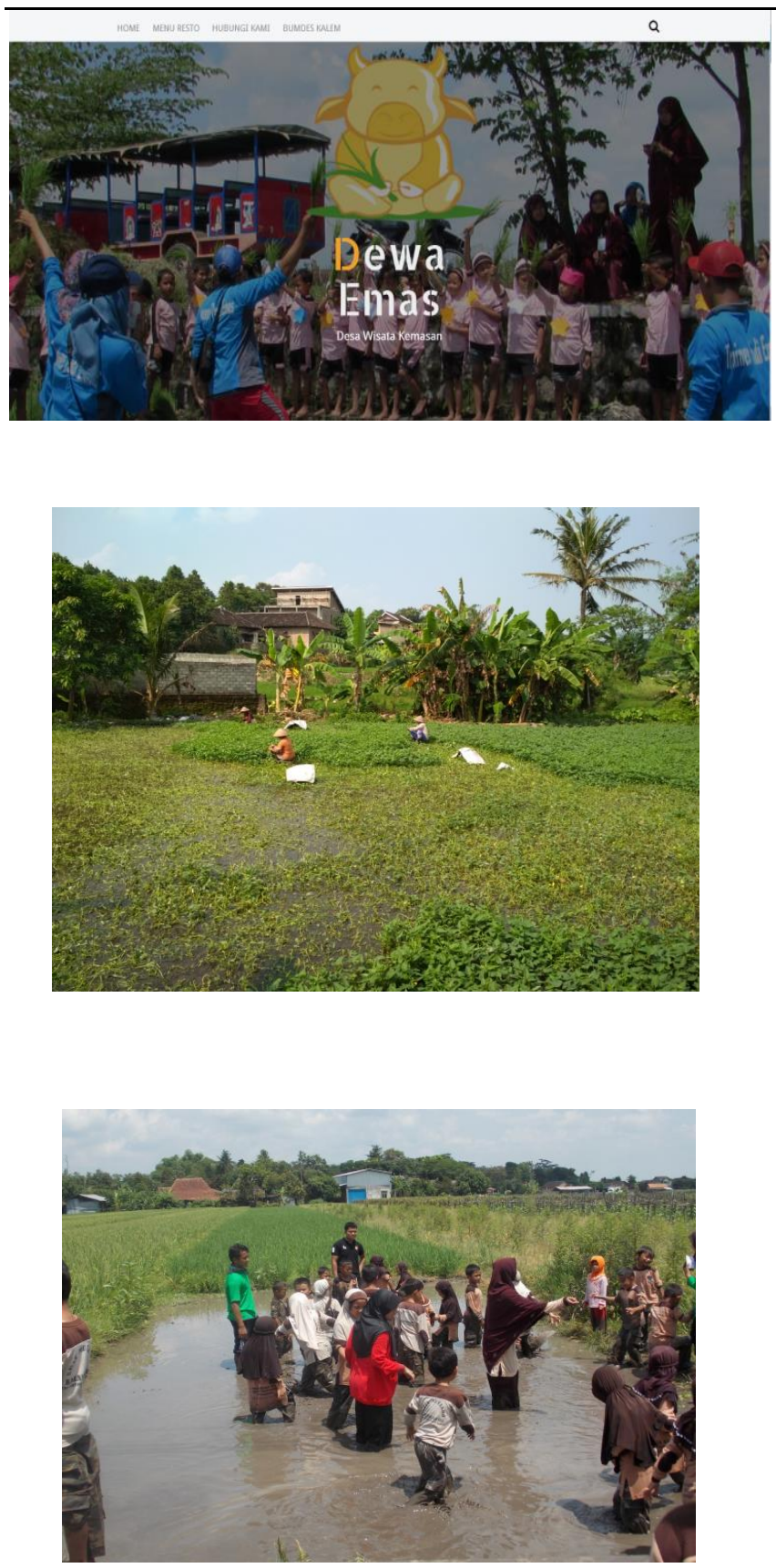

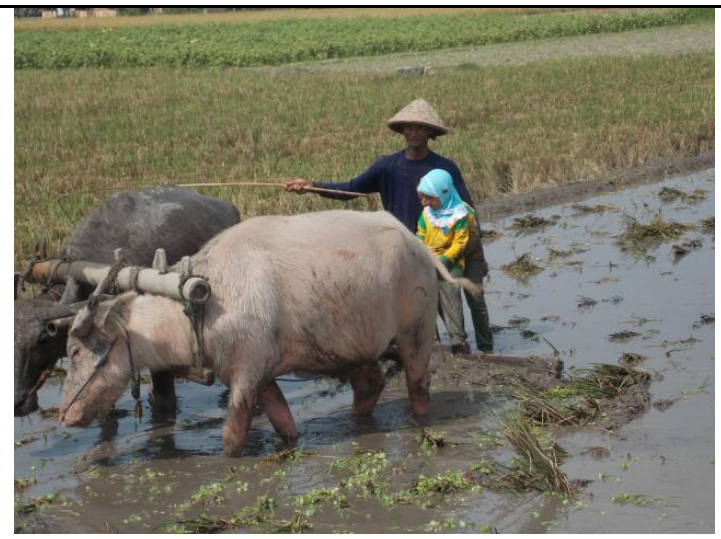

Wisata yang paling unik adalah Wisata Petik Kangkung, yang merupakan destinasi wisata unggulan di Desa Kemasan ini. Lahan yang luas dan dipenuhi oleh kangkung dimanfatkan masyarakat setempat sebagai area wisata edukasi. Anak-anak diajarkan bagaimana cara memilih dan memetik kangkung yang benar sehingga enak untuk disajikan sebagai makanan. Adanya edukasi pembuatan jamu dan roti, anak-anak juga merasakan bagaimana awal terbentuknya jamu dan roti yang sering dikonsumsi bermula, sehingga selain anak-anak mengerti bagaimana cara pembuatanya diharapkan pula anak-anak menjadi insan yang menghargai makanan dan minuman dan tidak suka membuang-buangnya.

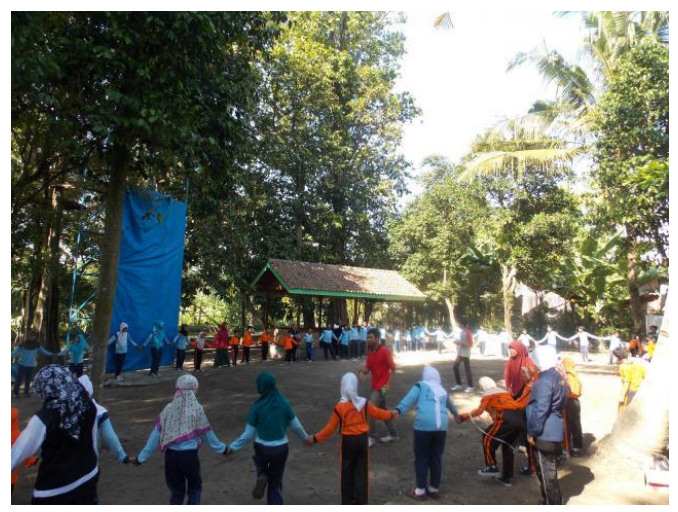

Kegiatan Wisata Anak (Fun education) di Desa Wisata Dewa Emas, Kemasan

Hasil wisata petik Kangkung, awalnya hanya digunakan sebagai oleh-oleh tanpa pengolahan, bahkan banyak yang kemudian ditinggal di tempat 
wisata. Setelah melakukan diskusi dengan beberapa Usaha Kecil Mikro (UKM), kemudian diperoleh ide untuk mengelola Kangkung tersebut. Awalnya hanya dibuat sayur, namun kemudian ada ide untuk mengolah Kangkung menjadi Kerupuk, maka kemudian dipilhkan beberapa orang yang kebetulan mempunyai keahlian membuat kerupuk

Hasil pengamatan di lapangan dan wawancara yang mendalam dengan Kepada Desa Kemasan, Bapak Susilo, dan Kepala BUMDes Kalem ibu Partini, mengungkapkan sebenarnya banyak hal yang harus dikembangkan untuk lebih memberdayakan usaha di Desa Kemasan. Usaha yang dijalankan selama ini hanya sebatas pengetahuan dan pemikiran yang sangat sederhana, misalnya, Kangkung hanya dibuat kerupuk, karena produk itu yang mudah dibuat. Belum ada pengetahuan lain yang cukup untuk membuat produk lain. Dengan kata lain tidak memiliki pengetahuan tentang diversifikasi produk dari kangkung ini. Demikian pula dalam produksi, asal jalan, tidak punya ilmu tentang cara produksi yang lebih efektif dan efisien.

Masalah lain adalah belum adanya sertifikasi halal, sekalipun bahan utama adalah Kangkung yang pasti halal. Namun ada bahan tambahan yang digunakan dalam proses produksi, sehingga perlu diuji kehalalannya. Oleh karena itu pada pengabdian ini akan fokus pada pendampingan pengajuan sertfikasi halal.

\section{METODE}

Proses pengabdaian akan dilakukan dengan metoda Participatory Rural Appraisal (PRA). Metoda ini mengedepankan proses pendampingan secara partisipatif dari seluruh UMKM. Adapun tahapan yang telah dilakukan dalam pendampingan meliputi:

1) Tahap Persiapan, meliputi pembentukan tim pendamping disertai dengan penjelasan tentang tupoksi untuk masing-masing pendamping.

2) Tahap Pelaksanaan Sosialisasi Sertifikasi Halal, dilakukan dengan pemberian materi tentang Destinasi Wisata Syariah di Kabupaten Boyolali dan Prosedur Pengajuan Sertifikasi Halal disampaikan salah satu Direktur Lembaga Pengkajian
Pangan, Obat-obatan dan Kosmetika (LPPOM MUI) Jawa tengah.

3) Tahap Pendampingan pengajuan sertifikasi halal, dilakukan mulai dalam bentuk pemberian konsultasi terhadap syarat-syarat yang harus dipenuhi untuk mendapatkan Sertifikasi Halal.

4) Tahap Evaluasi, dilakukan dengan membandingkan antara rencana kerja dengan realisasi kerja dan memberikan analisis tentang kendala-kendala yeng dihadapi dan pemberian solusi yang dibutuhkan.

5) Tahap Pelaporan dan Desiminasi, dilakukan pada dengan menyusun laporan dan melakukan desiminasi hasil pengabdian.

\section{HASIL DAN PEMBAHASAN}

Pengabdian dilakukan dengan beberapa kegiatan antara lain Sosialisasi dan Pendampingan pengajuan sertifikasi halal bagi UMKM berbasis Green Halal Product. Kegiatan ini diikuti oleh 40 pengusaha UMKM yang di wilayah Desa Kemasan, Kecamatan Sawit, Kabupaten Boyolali.

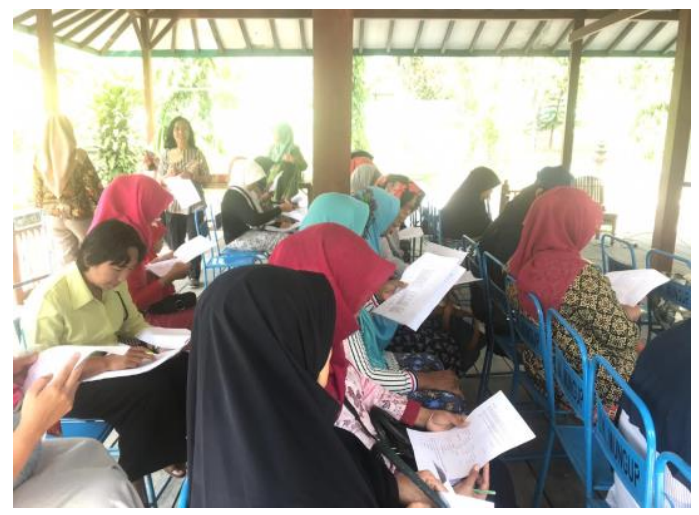

Gambar 5

Peserta yang mengikuti test

Sebelum dilakukan Sosialisasi, para peserta diberikan semacam pre test untuk memperoleh data terkait dengan pemahaman mereka terhadap Sertifikasi Halal. Setelah dilakukan sosialisasi dilakukan, kemudian dilakukan post test untuk pengukuran kembali pengetahuan mereka tentang sertifikasi halal. Jumlah peserta yang mengikuti test

$$
\text { Ekonomi, Sosial, dan Budaya }
$$


hanya sebanyak 22 peserta. Hasil analisis sebelum dan setelah dilakukan sosialisasi dapat dilihat pada table-tabel berikut.

Tabel 1

Uji Normalitas

\begin{tabular}{|r|r|r|r|r|r|}
\hline & Kategori & \multicolumn{4}{|c|}{ Shapiro-Wilk } \\
\cline { 4 - 6 } & Nilai & Statiistic & Statistic & \multicolumn{1}{c|}{ df } & \multicolumn{1}{c|}{ Sig. } \\
\hline Hasil nilai & Pre Test & .162 & .934 & 22 & .146 \\
Sosialisasi & Post Test & .128 & .967 & 22 & .638 \\
\hline
\end{tabular}

Sumber: Hasil Olah Data, 2019

Tabel 2

Paired Samples Statistics

\begin{tabular}{|l|c|r|r|c|}
\hline & Mean & \multicolumn{1}{c|}{$\mathrm{N}$} & $\begin{array}{c}\text { Std. } \\
\text { Deviation }\end{array}$ & $\begin{array}{c}\text { Std. Error } \\
\text { Mean }\end{array}$ \\
\hline PRE TEST & 68.1364 & 22 & 6.26628 & 1.33597 \\
POST TEST & 86.4545 & 22 & 4.03234 & .85970 \\
\hline
\end{tabular}

Sumber: Hasil Olah data, 2019

Tabel 1 dan Tabel 2 menunjukkan bahwa hasil Uji Normalitas dengan Shapiro-Wilk menunjukkan data berdistribusi noramal, dan uji Paired Samples Statistics menunjukkan bahwa rata-rata nilai pre test dan post test berbeda. Dengan demikian dapat disimpulkan bahwa adanya Sosialissi meningkatkan pemahaman peserta terhadap Sertifikasi Halal.

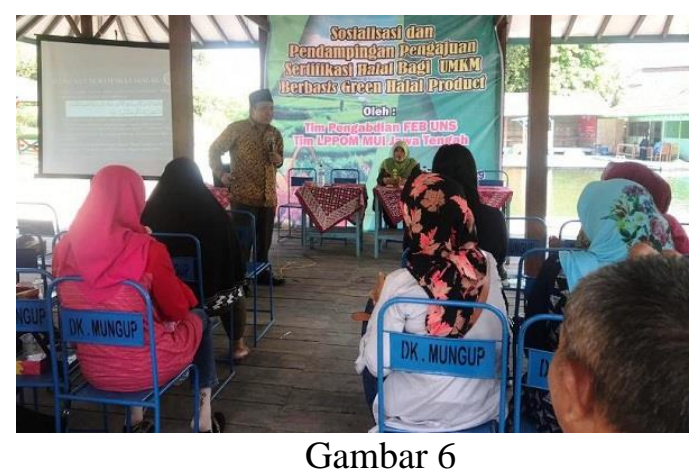

Sosialisasi Sertifikasi Halal

Kegiatan pengabdian akan dilanjutkan dengan pendampingan pengajuan Sertifikasi Halal bagi dua (2) UMKM terpilih yang sudah memiliki beberapa persyaratan yang harus dipenuhi. Persyaratan tersebut antara lain UMKM tersebut harus memiliki Ijin Usaha, PIRT dan Ijin Layak Sehat. Terkahir akhir diberikan bantuan alat produksi sesuai dengan kebutuhan UMKM dan kecukupan dana yang tersedia. Selanjutnya sampai dengan akhir pengabdian ini ada produk yang sudah tersertifikasi halal yaitu kerupukKangkung dan Kerupuk Wortel, sedangkan yang masih dalam proses adalah Serbuk Minuman Herbal.

Selain itu akan diadakan pelatihan Akuntansi untuk UMKM berbasis stanadar ETAP dan juga pendampingan dalam bentuk desain packing produk untuk meningkatkan volume penjualan.

Selanjutnya dalam pelaksanaan pendampingan diperoleh beberapa temuan khususnya untuk pengajuan Sertifikasi Halal terdapat beberapa kendala dantara lain: (1) tidak semua UMKM memiliki Ijin Usaha atau Legalitas Usaha, (2) persyaratan untuk mendapatkan PIRT dan Ijin Layak Sehat membutuhkan waktu yang cukup lama, dan (3) Biaya pengajuaan Sertifikasi Halal cukup mahal menurut ukuran keuangan UMKM, sehingga menghambat proses pengajuan Sertifikasi Halal.

\section{SIMPULAN}

Hasil pengabdian menyimpulkan beberapa temuan, antara lain:

1. Sebelum dilakukan pre tsest, pengetahuan pengusaha UMKM yang mengikuti Sosialisasi masih sangat rendah.

2. Setelah dilakukan Sosialisasi dan pos test, ternyata pengetahuan para pengusaha UMKM meningkat.

3. Pendampingan sangat perlu untuk dilakukan untuk memberikan kemudahan dalam mengajuakan Sertifikasi Halal.

\section{SARAN}

Sebaiknya Pemerintah Daerah menyederhanakan beberapa prosedur untuk mendapatkan PIRT dan Ijin Layak sehat bagi UMKM yang akan mengajukan Sertifikasi Halal,

Ekonomi, Sosial, dan Budaya

1045 
dan juga mengalokasikan dana misalnya dari Dana Desa khusunya yang berkaitan dengan aktifitas pemberdayaan masyarakat.

\section{UCAPAN TERIMAKASIH}

Kegiatan ini bisa berjalan dengan lancar tentu saja didukung oleh pihak lain selain tim pengabdian ini sendiri. Untuk itu pantaslah kiranya Tim mengucapkan banyak terima kasih kepada:

1. Ketua Lembaga Penelitian dan Pengabdian kepada Masyarakat UNS

2. Direktur LPPOM MUI Jawa tengah.

3. Kepala Desa Kemasan, Kecamatan Sawit, Kabupaten Boyolali.

4. Pengurua Badan Usaha Milik Desa (BUMDes) Karya Lestari Manunggal

5. Para peserta telah bersedia mengikuti pengabdian ini.

6. Semua pihak yang telah membantu kelancaran pelaksanaan kegiatan pengabdian ini. Semoga kegiatan ini dapat memberikan manfaat kepada masyarakat.

\section{REFERENSI}

Dewan Syariah Nasional, Majelis Ulama Indonesia. 2016. Fatwa No 108 tentang Pedoman Penyelenggaraan Pariwisata Berdasarkan Prinsip Syariah.

Falikhatun, Anis Wijayanto, dan Sri Hanggana. 2017. Peningkatan Kinerja Keuangan Badan Usaha Milik Desa (Bumdes) Dengan Mengembangkan Wisata Desa Berbasis Syariah. Laporan Penelitian PNBP UNS.

Ikatan Akuntan Indonesia. 2010. Standar Akuntansi Keungan Entitas Tanpa Akuntabilitas Publik (SAK ETAP), Penerbit: IAI, Jakarta.

Widagdyo, Kurniawan Gilang. 2015. Analisis Pasar Pariwisata Halal di Indonesia. The Journal of Tauhidinomics Vol. 1 No. 1 (2015): 73-80

Zamani-Farahani, H., \& Henderson, J. C..2010. Islamic tourism and managing tourism development in Islamic societies: The cases of Iran and Saudi Arabia. The International Journal of Tourism Research, 12(1), 79. 